\title{
Effects of biochar on soil water retention curves of compacted clay during wetting and drying
}

\author{
James Tsz Fung Wong ${ }^{1} \cdot$ Ka Lai Chow $^{2} \cdot$ Xun Wen Chen ${ }^{4,5} \cdot$ Charles Wang Wai $\mathrm{Ng}^{1} \cdot$ Ming Hung Wong $^{3}$
}

Received: 26 April 2021 / Accepted: 19 October 2021

(c) The Author(s) 2022

\begin{abstract}
Compacted clay possesses a low water permeability and has been widely used in geo-environmental facilities such as landfill cover systems. Recent studies revealed the potential applications of compacted biochar-amended clay (BAC) as an alternative landfill cover soil. However, the effects of biochar on the soil water retention curves (SWRCs) of clay at low suction are not known. This study can help fill this knowledge gap by measuring the wetting and drying SWRCs of clay and BAC (20\% biochar). Soils were compacted in instrumented soil columns and subjected to a wetting and drying cycle, and soil water content and suction were measured along with the soil depth. BAC was saturated faster when compared with clay. Upon drying, the soil water content of clay at $65 \mathrm{~mm}$ depth dropped to almost zero, while about $5 \%$ of water was retained in BAC. It showed that biochar increased the soil water retention capacity of compacted clay upon drying. SWRCs showed that biochar-clay composite possesses a higher soil water retention capacity at a low soil suction range $(<1000 \mathrm{kPa})$ compared with clay alone. It revealed the benefits of using compacted biochar-clay composite as a hydraulic barrier to minimize desiccation-induced cracks and potentially promote its serviceability, especially in arid and semi-arid regions. The composite is also a carbon sink material that can reduce landfill gas emissions and pollutant leaching.
\end{abstract}

\section{Highlights}

- SWRCs of compacted biochar-clay composite at low suction was first studied

- Biochar application increased soil water holding capacity of compacted clay

- Biochar-amended clay (BAC) was saturated faster when compared with clay

James Tsz Fung Wong and Ka Lai Chow are co-first authors and contributed equally to this work

Charles Wang Wai $\mathrm{Ng}$

cecwwng@ust.hk

Ming Hung Wong

minghwong@eduhk.hk

1 Department of Civil and Environmental Engineering, The Hong Kong University of Science and Technology, Clear Water Bay, Kowloon, Hong Kong, SAR, China

2 Department of Geography, Hong Kong Baptist University, Kowloon Tong, Hong Kong, SAR, China

3 Consortium on Health, Environment, Education and Research (CHEER), Department of Science and Environmental Studies, The Education University of Hong Kong, Tai Po, Hong Kong, SAR, China
- BAC retained more water after drying when compared with clay

4 Guangdong Provincial Key Laboratory of Soil and Groundwater Pollution Control, School of Environmental Science and Engineering, Southern University of Science and Technology, Shenzhen 518055, China

5 State Environmental Protection Key Laboratory of Integrated Surface Water Groundwater Pollution Control, School of Environmental Science and Engineering, Southern University of Science and Technology, Shenzhen 518055, China 
Keywords Soil amendment · Biochar-clay composite $\cdot$ Soil carbon $\cdot$ Soil suction $\cdot$ Soil depth

\section{Introduction}

Compacted clay has been widely used in geo-environmental facilities. For instance, in arid and semi-arid areas with a relatively low annual precipitation, the compacted clay layer, known as clay liner serving as a hydraulic barrier, was adopted as a key component of the landfill cover system (USEPA 1989; Cossu 2018; Favaretti and Cossu 2018). In the natural environment, soils are subjected to numerous wetting-drying and heating-cooling cycles, which can cause volume shrinkage of soils and hence the formation of cracks (Mu et al. 2020; Tang et al. 2021). Due to the desiccationinduced cracks, leakage is commonly observed in regions under certain unfavorable weather conditions (Albright et al. 2006; Melchior 1997). The serviceability of the clay layer as a hydraulic barrier is thus compromised. Therefore, claybased composites, such as nanomaterial-clay composites, were proposed for preventing cracks and reducing hydraulic conductivity (Ng and Coo 2014).

Recently, biochar-clay composite has been used as an alternative landfill cover material (Wong et al. 2017). Biochar is a carbon-rich material produced by heating biomass at $200-700{ }^{\circ} \mathrm{C}$ with a limited oxygen supply. Biochar has been considered a carbon-sink material for environmental remediation (Lehmann and Joseph 2009). Adding biochar to soil can profoundly affect soil physical properties (Chen et al. 2010, 2016; Major et al. 2010). For example, biochar addition led to a lower (by two orders of magnitude) gas permeability of clay (Wong et al. 2015), a higher saturated hydraulic conductivity of clay (Wong et al. 2018), less volume change of sand during heating and cooling (Cheng et al. 2018), and altered soil water retention curves (SWRCs) of clay at high soil matric suction (48-125 MPa) (Wong et al. 2017). Particularly, Wong et al. (2018) showed that adding biochar to clay increased the saturated hydraulic permeability by one order of magnitude when the biochar ratio was $20 \%(\mathrm{w} / \mathrm{w})$.

However, the hydraulic barriers subjected to wetting and drying cycles are commonly unsaturated, and the matrix suction is within a smaller range $(<1.5 \mathrm{MPa})$ rather than 48-125 MPa. Unsaturated hydraulic conductivity can be predicted from SWRCs (van Genucheten 1980), which describe the relationship between soil matric suction (or negative water potential) and soil water content during wetting and drying processes. There are different curves for wetting and for drying, and also different curves for different soils. The SWRC is fundamental to describe soil behavior (Atkinson 2007; Zhou and Chen 2021).

For the biochar-clay composite (proposed as a hydraulic barrier), it is essential to investigate its SWRCs during wetting and drying because the SWRCs ultimately determine the performance (or serviceability) of the hydraulic barrier. Although existing studies on biochar-amended soils provide helpful information on how biochar can change SWRCs, they primarily focused on non-compacted agricultural soils (Liu et al. 2016; Moragues-Saitua et al. 2017; Wang et al. 2019) and non-compacted clay (Rasa et al. 2018). The effects of biochar on SWRCs are not conclusive. For instance, Jeffery et al. (2015) concluded from their field investigation conducted in the Netherlands that biochar did not significantly affect the SWRC of sandy soil.

Meanwhile, biochar-clay composites used as barriers are usually highly compacted (degree of compaction at $90 \%$ ) to achieve a relatively low water permeability $\left(10^{-10} \mathrm{~m} \mathrm{~s}^{-1}\right)$ (Ng et al. 2016) and higher soil stability. The degree of compaction (as a reflection of the soil density) has profound effects on SWRCs (Ng and Pang, 2000). Wong et al. (2017) reported the SWRCs of compacted biochar-amended clay (BAC) at a high matric suction range $(48-125 \mathrm{MPa})$ and found that adding $20 \%(\mathrm{w} / \mathrm{w})$ peanut shell biochar increased the soil water holding capacity of clay by $>59 \%$. However, the effects of biochar on the SWRC, especially at a low soil suction range $(<1500 \mathrm{kPa}$, essential for regions with a high level of precipitation), are not yet studied. Under natural conditions, the clay layer is usually at a low suction range $(<1500 \mathrm{kPa})$ when the water content is high. The influence of biochar amendment on clay as a hydraulic barrier is still unclear.

Therefore, it shows the importance of understanding the SWRCs of the biochar-clay composite with relatively high soil water contents but not saturated (low soil suction). We hypothesize that adding biochar can affect the unsaturated SWRCs of clay at a low suction range $(<1500 \mathrm{kPa})$ and thus the hydraulic conductivity (related to water infiltration) of the clay. Biochar amendment in clay can probably maintain a relatively high suction corresponding to relatively high water content, and thus prevent/minimize desiccationinduced cracks and improve the serviceability of the hydraulic barrier. This study aims to investigate the effects of biochar (derived from peanut shells) on the wetting and drying SWRCs of the compacted clay using soil columns.

\section{Materials and methods}

\subsection{Testing materials}

Kaolin clay bought from Jiangsu Province of China (China Kaolin Co. Ltd.) was used in this study, and biochar used was derived from peanut shells. Production details of the 
Table 1 Basic geotechnical properties of kaolin clay and biocharamended clay (Ng et al. 2016; Wong 2017)

\begin{tabular}{lll}
\hline & Kaolin Clay & $\begin{array}{l}\text { Biochar- } \\
\text { amended } \\
\text { Clay }\end{array}$ \\
\hline $\begin{array}{l}\text { Biochar content }(\%) \\
\text { Specific gravity }\left(\mathrm{G}_{\mathrm{s}}\right)\end{array}$ & 0 & 20 \\
$\begin{array}{l}\text { Atterberg limits } \\
\text { Liquid limit (LL) }\end{array}$ & 2.52 & 2.41 \\
Plastic limit (PL) & 70 & 78 \\
Plasticity index (PI) & 33 & 49 \\
Standard compaction curve & 37 & 29 \\
Maximum dry density $\left(\mathrm{kg} \mathrm{m}^{-3}\right)$ & 1264 & 1120 \\
Optimum water content $(\%)$ & 36.18 & 41.00 \\
Void ratio $(e)$ & 1.06 & 1.65 \\
Estimated degree of saturation $(S, \%)$ & 73.3 & 76.5 \\
\hline
\end{tabular}

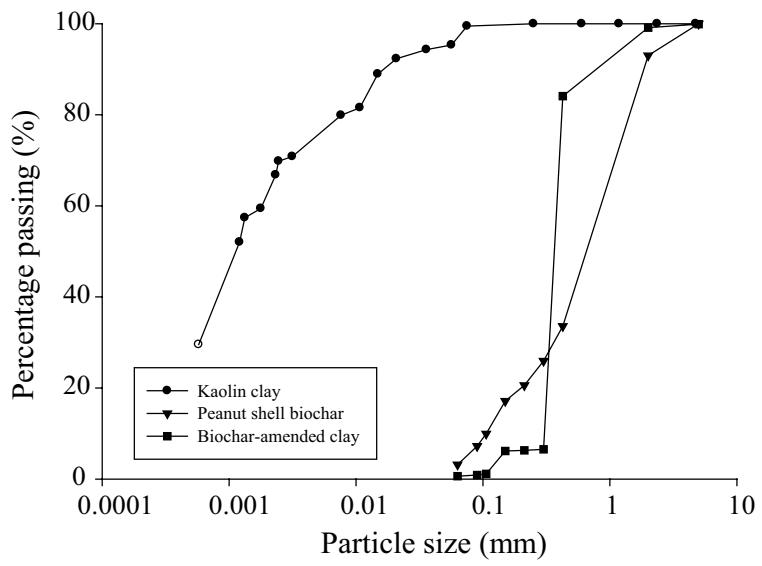

Fig. 1 Particle-size distribution of kaolin clay, biochar, and biocharamended clay

biochar were reported in Wong et al. (2015). Briefly, the peanut shells were heated at $5-10{ }^{\circ} \mathrm{C} / \mathrm{min}$ and retained at $\sim 500{ }^{\circ} \mathrm{C}$ for $30-40 \mathrm{~min}$. Approximately $30 \%$ of the biomass was converted into biochar. During pyrolysis, nitrogen gas was pumped into the heating chamber to maintain an oxygen-deficit environment. The biochar product was passed through a $5-\mathrm{mm}$ sieve and subsequently a $425-\mu \mathrm{m}$ sieve to obtain a more homogenized biochar-amended clay sample and prevent possible preferential flow. Basic geotechnical properties of clay and BAC, including specific gravity $\left(\mathrm{G}_{\mathrm{s}}\right)$, Atterberg limits, standard compaction curves, and void ratio $(e)$, are summarised in Table 1 ( $\mathrm{Ng}$ et al. 2016; $\mathrm{Ng}$ and Pang 2000). The addition of biochar reduced the specific gravity and maximum dry density of kaolin clay but increased the plasticity, optimum water content, and void ratio (Table 1). Figure 1 shows the particle size distribution of clay, biochar, and BAC. The BET-specific surface areas of clay and $425 \mu \mathrm{m}$-sieved biochar were $41.46 \pm 14.16$ and $151.24 \pm 47.38 \mathrm{~m}^{2} \mathrm{~g}^{-1}$, respectively (Wong, 2017).

\subsection{Soil column}

Figure 2 shows the soil column and the constant-head water supply system adopted in the present study. The soil column was made of a transparent acrylic cylinder, with $735 \mathrm{~mm}$ in height, $140 \mathrm{~mm}$ of inner diameter, and $10 \mathrm{~mm}$ wall thickness. The top and bottom boundary water flow conditions of the soil column were controlled. The compacted soil was subjected to a wetting and drying cycle by ponding and being subjected to natural evaporation, respectively. During wetting (ponding), a constant-head water supply system was used to create a constant water head infiltration. The system composed of four components included a Mariotte's bottle serving as a water storage tank, a balance, a plastic tube connecting the Mariotte's bottle, and the soil column (McCarthy 1934). The Mariotte's bottle was composed of a transparent acrylic cylinder, and a copper tube inserted and sealed at the centre of the bottle. The details about Mariotte's bottle can be found in $\mathrm{Ng}$ et al. (2016). Appendix A shows the instrumented soil column at the wetting stage.

During drying (natural evaporation), the constant-head water supply system and the cover of the soil column were removed. The compacted soil was subjected to drying by evaporation. At the bottom of the soil column, a valve was installed to control its drainage. It was opened during ponding and closed during drying. Appendix B shows the instrumented one-dimension (1D) soil column at the drying stage.

\subsection{Instrumentation of the soil column and calibration of sensors}

Figure 2 illustrates the instrumentation of the soil columns. The small-tip tensiometers (STs) (2100F, Soilmoisture Equipment Corp., USA), heat dissipation matric potential sensors (HDs) (229, Campbell Scientific Inc., USA), and theta-probe soil moisture probes (TPs) (ML2x, Delta-T Devices, UK) were installed. STs were used to measure soil suction from 0 to $85 \mathrm{kPa}$, HDs for higher range suction measurement (60-2500 kPa), and TPs for measuring soil volumetric water content (VWC). The STs, HDs, and TPs were installed at $65,215,365$, and $515 \mathrm{~mm}$ below the soil surface. Soil suction and soil water content were measured at the same levels in order to investigate their correlations. All sensors were inserted into the soil columns through the predrilled holes. The diameter of the predrilled holes was made 1-2 mm smaller than the sensor, which ensured good contact between the sensor and the soil.

All the STs were calibrated before installation in accordance with the guidance provided by the manufacture (Campbell Scientific Inc., USA). For TPs, soil specific 

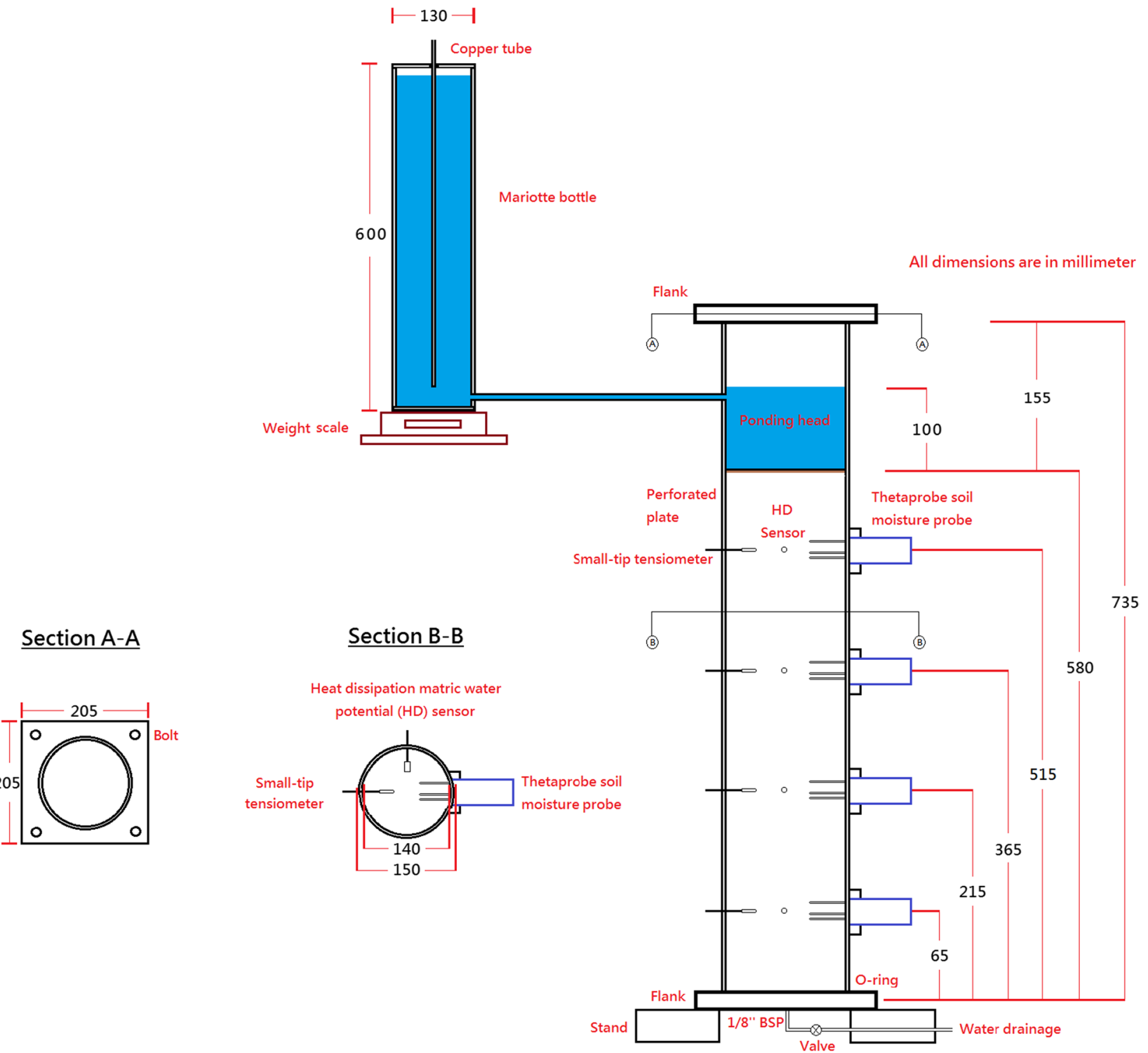

Fig. 2 Schematic diagram of the instrumented one-dimensional soil column

sensor calibration was conducted at four different soil water contents in accordance with the guidance provided by the manufacture (Delta-T Devices, UK). The HD sensors were calibrated for the soil suction ranging from 0 to $1 \mathrm{MPa}$. Four different soil suction values $(0,0.25,0.5$, and $1 \mathrm{MPa})$ were induced using the osmotic technique (OT) (Delage and Cui 2008). In brief, different levels of soil suction were controlled by the different concentrations of polymer in the solution. The polymer polyethylene glycol $\left(\mathrm{PEG}, \mathrm{C}_{2 \mathrm{n}} \mathrm{H}_{4 \mathrm{n}}+2 \mathrm{O}_{\mathrm{n}+1}\right.$ ) with a molecular weight of 20,000 (Sigma-Aldrich Chemistry, Darmstadt, Germany) was used to prepare the solution. The semi-permeable membrane (molecular weight cut-off (MWCO): 12-14,000; Spectra/ Por, Spectrum Labs, CA, USA) was used to separate the soil sample and the solution. The empirical calibration relationship between the PEG solution concentration and induced suction can be expressed by the following equation (Delage and Cui 2008):

$s=11 c^{2}$

where $s$ is induced soil (MPa) and $c$ is the concentration of PEG (w/w).

It should be noted that the relationships between the heat dissipation of the sensors and matric suction are hysteretic. It depends on the wetting and drying history of the sensors themselves (Dane and Topp 2002). It has been shown that the hysteresis beyond $85 \mathrm{kPa}$ (suction $<85 \mathrm{kPa}$ was measured using STs in the present study) was relatively small 
(Leong et al. 2012). The readings of sensors are stable from one sensor to sensor provided the sensors have the same saturation history (Shuai et al. 2000; Feng et al. 2002; Leong et al. 2012), which was considered in the present study.

Automatic data acquisition systems were used in this study. STs were equipped with pressure transducers and connected to the DL2e data logger (Delta-T Devices, UK). The HDs were connected to the CR1000 datalogger (Campbell Scientific Inc., USA), and the TPs to the DL2e data logger. Computer programs were set for the data sampling and communication between the sensors, data logger and a personal computer.

\subsection{Preparation of the soil columns}

Air-dried kaolin clay was mixed with $20 \%$ (by dry weight) $425 \mu \mathrm{m}$-sieved and air-dried biochar to produce the biocharamended clay (BAC). The ratio of biochar:clay was based on our previous study that adding $20 \%$ biochar drastically increased the soil water holding capacity of clay (Wong et al. 2017). Both kaolin clay and BAC were added with deionised water to their optimum water content. The optimum water content refers to the water content at the peak of the compaction curve. It represents the soil water content at which the dry soil density is at maximum for given compaction energy (Fredlund et al. 2012). The application of biochar alters both particle size and pore size distribution of compacted clay (Wong et al. 2018). Our previous findings noted that biochar increased the optimum water content of clay and the soil water holding capacity on both drying and wetting paths (Wong et al. 2017).

The wet soils were then sieved through a $2 \mathrm{~mm}$ sieve and stored in an air-tight plastic bag for water equilibrium for two days. A thin layer of vacuum grease was smeared on the inner wall of the soil column to reduce any preferential flow of water between the soil column interface. The soils were compacted into 1D soil columns at a $95 \%$ degree of compaction (DOC). Each soil column was compacted in 20 lifts (29 mm each) to ensure the uniformity of soil density. Figure 3 shows the target and actual dry density profiles of the soil columns. The variations between them for clay and BAC columns were only 1.82 and $2.73 \%$, respectively.

\subsection{Wetting and drying procedure}

After soil compaction and instrumentation, soil columns were subjected to a wetting-drying cycle. Wetting was achieved by using the constant-head water supply system. An approximately $100 \mathrm{~mm}$ constant ponding head was applied on top of the soil surface. The top of the soil column was covered and sealed by a plastic cover to prevent evaporation. The valve at the bottom of the column was opened

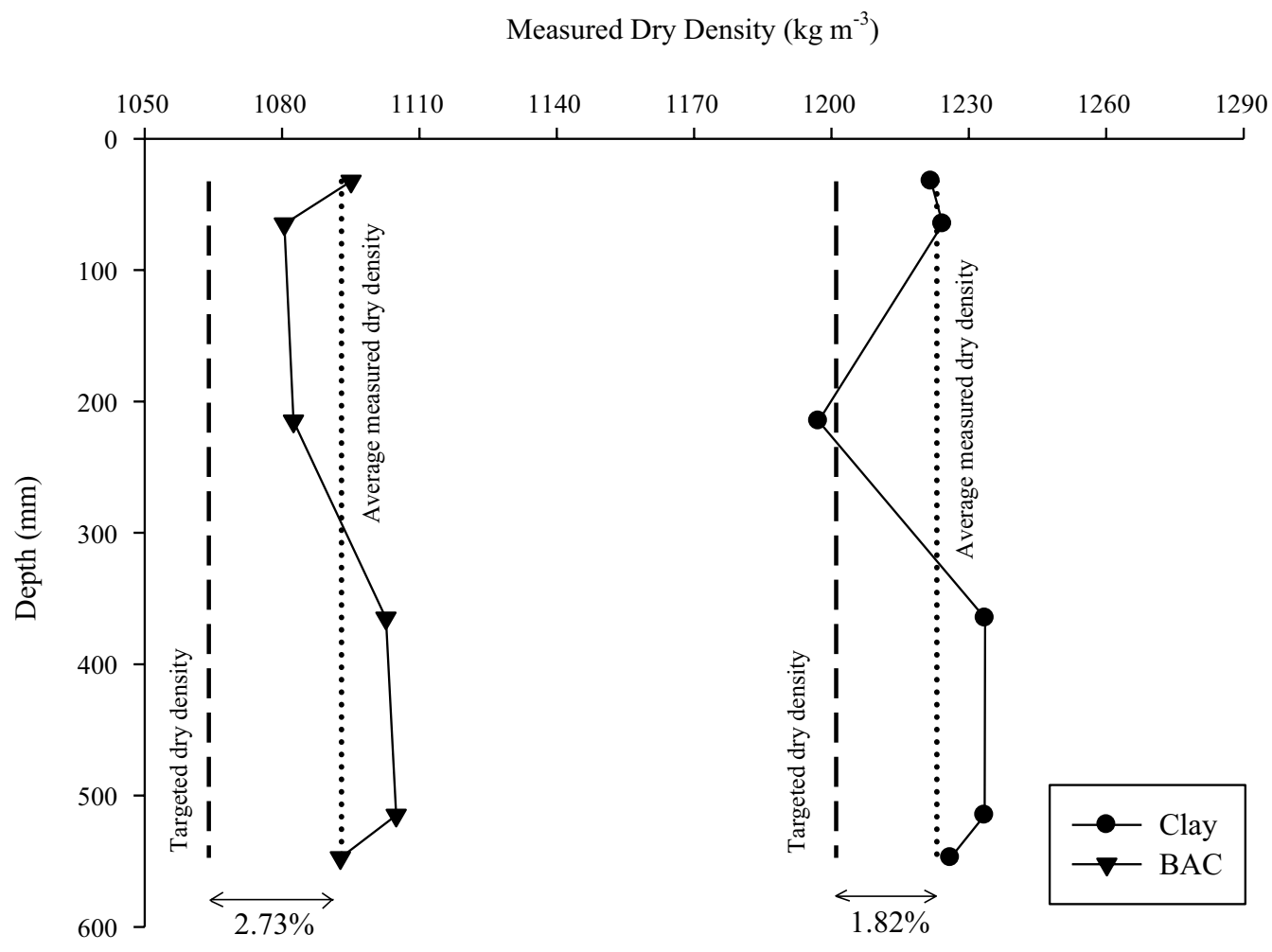

Fig. 3 Measured dry density profiles of soil columns after the test 
to generate a free drainage boundary condition. During the ponding stage, the water infiltration, change in volumetric water content, and pore-water pressures along the column depth were continuously recorded. It was considered to be the end of the ponding stage when the changes of volumetric water contents were less than $0.01 \%$ for $24 \mathrm{~h}$, and porewater pressures at all depths were recorded as $0 \mathrm{kPa}(\mathrm{Ng}$ and Leung 2012).

After ponding (wetting process), evaporation (drying process) was conducted subsequently. The constant-head water supply system and the plastic cover on top of the soil column were removed. Therefore, the soil surface of the column (top boundary) was subjected to evaporation by natural ventilation. The valve at the column bottom was closed to control the bottom boundary water flow rate to be zero. The variations of pore-water pressure and volumetric water content were recorded and monitored continuously.

After the wetting-drying cycle, soil samples were collected at different depths of each column. The dry density and final volumetric water content of the samples were determined to verify and evaluate the performances of the TPs by cross-checking.

\section{Results and discussion}

\subsection{Response of pore-water pressure (PWP)}

Figure $4 \mathrm{a}, \mathrm{b}$ show the measured variations of PWP with time at depths: $65,215,365$, and $515 \mathrm{~mm}$, respectively. The ponding stage (wetting process) was between Days 1 and 165 , while the evaporation stage (drying process) was from Days 165 to 308. The PWPs of both clay and BAC columns at $65 \mathrm{~mm}$ depth and $215 \mathrm{~mm}$ depth decreased gradually at a similar rate $(\sim 0.2 \mathrm{kPa} /$ day) (Fig. $4 \mathrm{a})$. The PWPs at clay depth of $65 \mathrm{~mm}$ and BAC were increased to $0 \mathrm{kPa}$ at Days 150 and 90, respectively. For clay depth of $215 \mathrm{~mm}$, PWPs of clay and BAC columns also dropped to $0 \mathrm{kPa}$ at Days 160 and 130, respectively. However, it should be noted that the soils were compacted at their optimum water contents (OWC), and the OWC of BAC (41\%) was higher compared with clay (36\%). It should be noted that the pore-water pressure data between days 165 and 230 were not available due to the failure of the data logging system.

Soil columns were dried by evaporation started from Day 165. Figure 5 shows the surface of the soil column at the start of the evaporation process (same day as the end of the wetting process). During drying, suction was induced at the soil surface. The total head at the soil surface, i.e., the sum of elevation head and pore-water pressure head was reduced. Therefore, the total head at the lower depth of the column was higher than that of the soil surface and water migrated upward during drying. Water was then moving into the atmosphere according to the psychrometric law (Delage et al. 1998). At Day 230, the PWPs at clay depth of $65 \mathrm{~mm}$ of clay and BAC columns were similar at about $-450 \mathrm{kPa}$, while PWPs at other depths of both columns were similar (Fig. 4a). Afterwards, the drying rates of clay at depths 65 and $215 \mathrm{~mm}$ were higher when compared with BAC. At Day 240, the PWPs of clay at depths 65 and $215 \mathrm{~mm}$ decreased to - 1076 and $-1054 \mathrm{kPa}$, respectively. While for BAC, the PWPs at depths 65 and $215 \mathrm{~mm}$ only decreased to -853 and $-672 \mathrm{kPa}$, respectively. For kaolin clay, the PWP did not increase significantly after Day 240, and PWPs of depths 65 and $215 \mathrm{~mm}$ at the end of the test (Day 308) were -1177 and $-1145 \mathrm{kPa}$, respectively. For BAC, PWP decreased continuously until the end of the test. The PWPs at depths 65 and $215 \mathrm{~mm}$ of BAC were -1018 and $-963 \mathrm{kPa}$, respectively. Similar trends were observed at depths 365 and $515 \mathrm{~mm}$ for both clay and BAC (Fig. 4b). Figure 5 shows the surface of the soil columns at the end of the drying process (Day 308). More substantial soil shrinkage and cracks formation were observed on the soil surface of kaolin clay compared with the BAC. Shrinkage and the subsequent crack formation upon drying are commonly reported for clayey soils (Coo et al. 2016; Fernandes et al. 2015; Krisdani et al. 2008). Therefore, it increases both gas and water permeability of compacted clay layer. According to Albright et al. (2006), the presence of desiccation cracks increased the water permeability of compacted clay by three orders of magnitude. The application of biochar alters the particle size distribution and pore size distribution of clay (Wong et al. 2018). It implies that biochar can potentially reduce desiccation-induced shrinkage and the subsequent crack formation of compacted kaolin clay during drying.

Figure $4 \mathrm{~b}$ shows the decrease in PWPs at depths 365 and $515 \mathrm{~mm}$ with a similar observation. The PWPs at clay depth of $365 \mathrm{~mm}$ and BAC columns decreased to $0 \mathrm{kPa}$ at Days 155 and 145, respectively. For a depth of $515 \mathrm{~mm}$, PWPs of clay and BAC columns were saturated at Days 150 and 140, respectively. Results from the drying stage showed that biochar addition reduced the rate of building up negative porewater pressure, i.e., BAC dried more slowly than pure clay, along the compacted clay column. It seemed biochar amendment did not affect the wetting, but reduced the drying rate of the materials (Fig. 4). It is probably caused by the porous characteristics of the biochar, which contribute to the slower drying rate. Higher water contents in soils amended with biochar than pure soils were commonly observed (Wang et al. 2019; Lu et al. 2020).

\subsection{Response of volumetric water content (VWC)}

Figure $6 \mathrm{a}, \mathrm{b}$ show the measured variations of VWCs with time at depths 65 and $215 \mathrm{~mm}$, and depths 365 and $515 \mathrm{~mm}$, respectively. The VWCs of clay at depths 65 and $215 \mathrm{~mm}$ did not increase during the wetting stage. The VWC at 

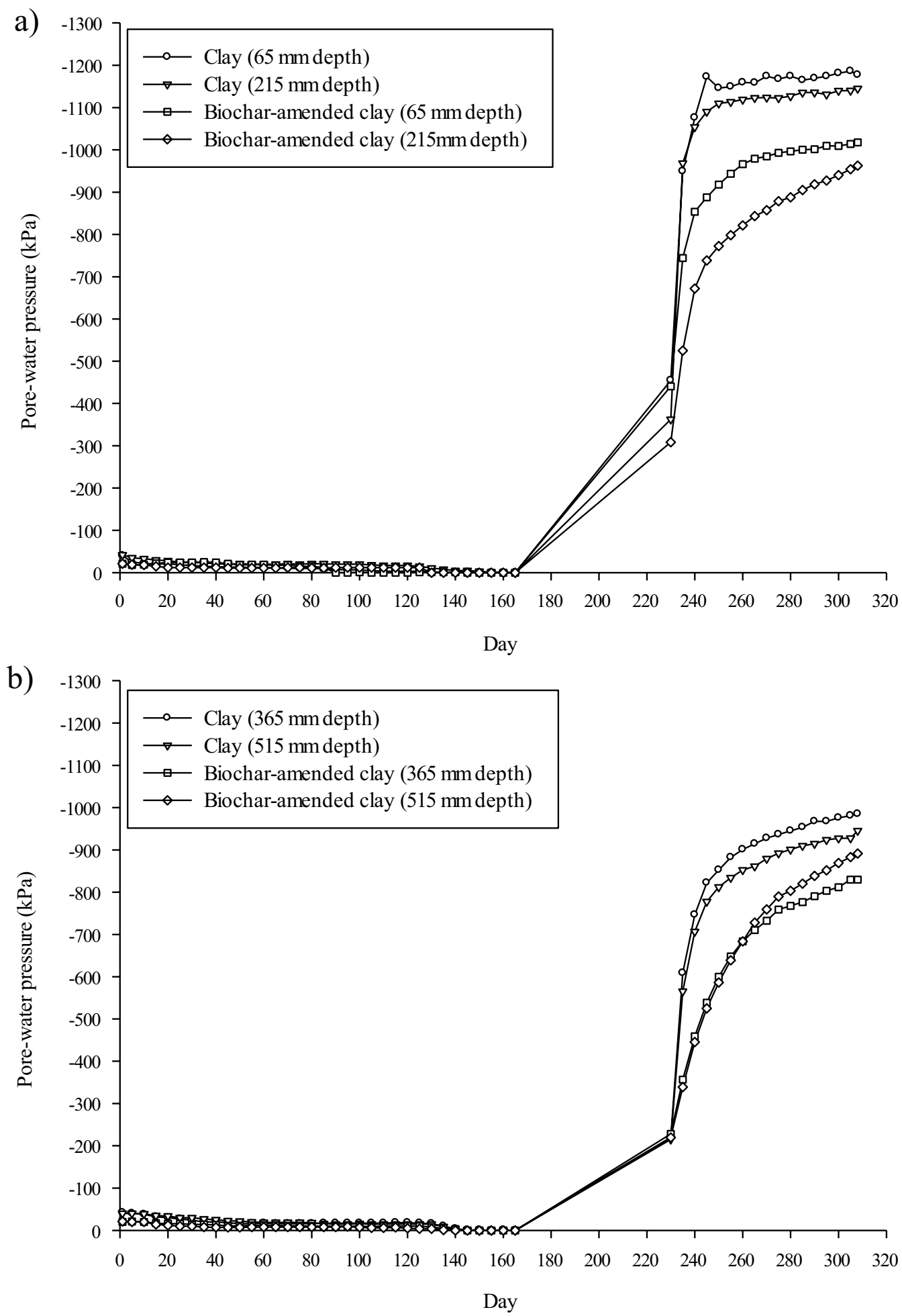

Fig. 4 Measured variations of pore-water pressure with time a Rows A and B, b Rows C and D

$65 \mathrm{~mm}$ of clay increased from 37.9 to $41.3 \%$ during the first five days and steadily increased to $43.7 \%$ at the end of ponding. However, the VWC at $215 \mathrm{~mm}$ of clay was only slightly increased from 38 to $40 \%$ after ponding for 165 days. Similar trends were observed at depths 365 and $515 \mathrm{~mm}$, except for BAC depth of $515 \mathrm{~mm}$. The highest VWC of $50.9 \%$ of BAC was recorded at a depth of $515 \mathrm{~mm}$, at the end of the wetting stage (Fig. 6b). 
a)

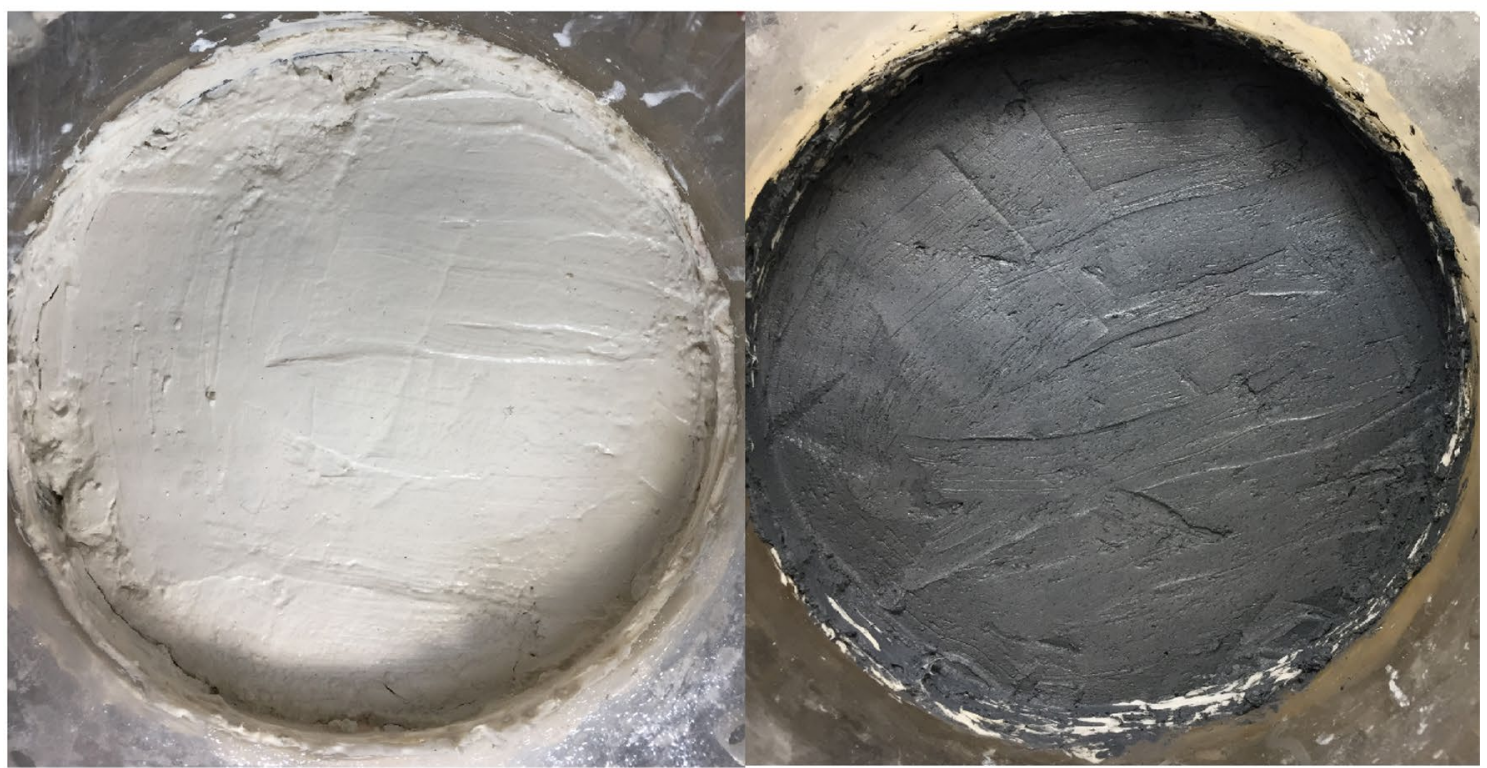

Kaolin clay

\section{Biochar-amended clay}

b)

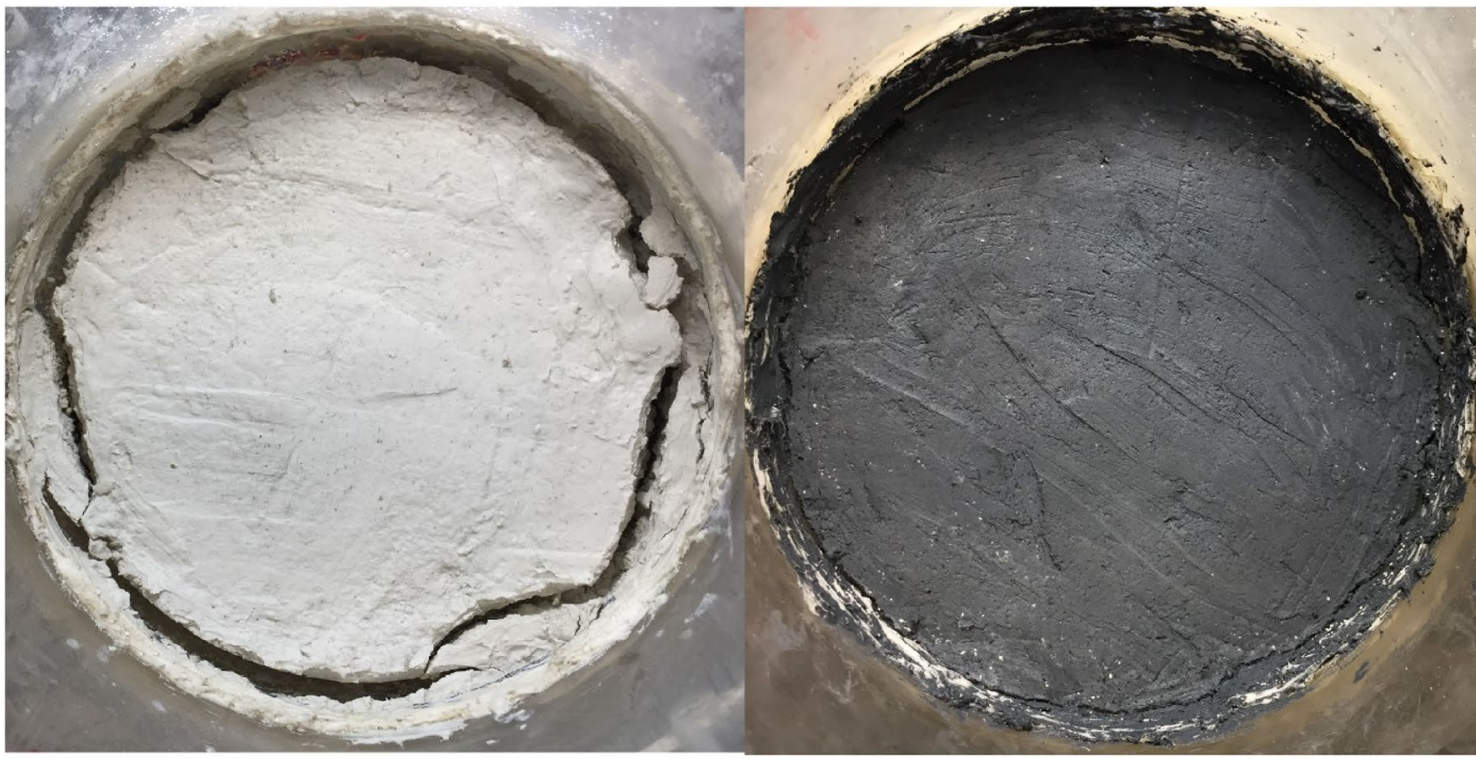

Kaolin clay

Biochar-amended clay

Fig. 5 The surface of soil columns at $\mathbf{a}$ the start and $\mathbf{b}$ the end of the drying phase

During drying, the VWCs at depths 65 and $215 \mathrm{~mm}$ of clay and BAC columns decreased slightly until Day 230 and dropped with a higher rate to the end of the test (day 308) (Fig. 6a). The VWC at clay depth of $65 \mathrm{~mm}$ decreased $(\sim 0.5 \% /$ day) from 44 to $1 \%$ throughout the drying process, which was the lowest recorded VWC in the clay column. At clay depth of $215 \mathrm{~mm}$, VWC decreased with a lower rate
( $\sim 0.3 \% /$ day), and the VWC at the end of the test was $16 \%$. The VWCs at depths 65 and $215 \mathrm{~mm}$ of BAC decreased on average with a similar rate $(\sim 0.3 \% /$ day $)$. However, VWC at clay depth of $215 \mathrm{~mm}$ became steady at Day 295, with the final VWC $15.7 \%$, while the final VWC at clay depth of $65 \mathrm{~mm}$ was $5.4 \%$. The final VWC of BAC was higher than that of clay at the same soil depth. The decreasing trends 

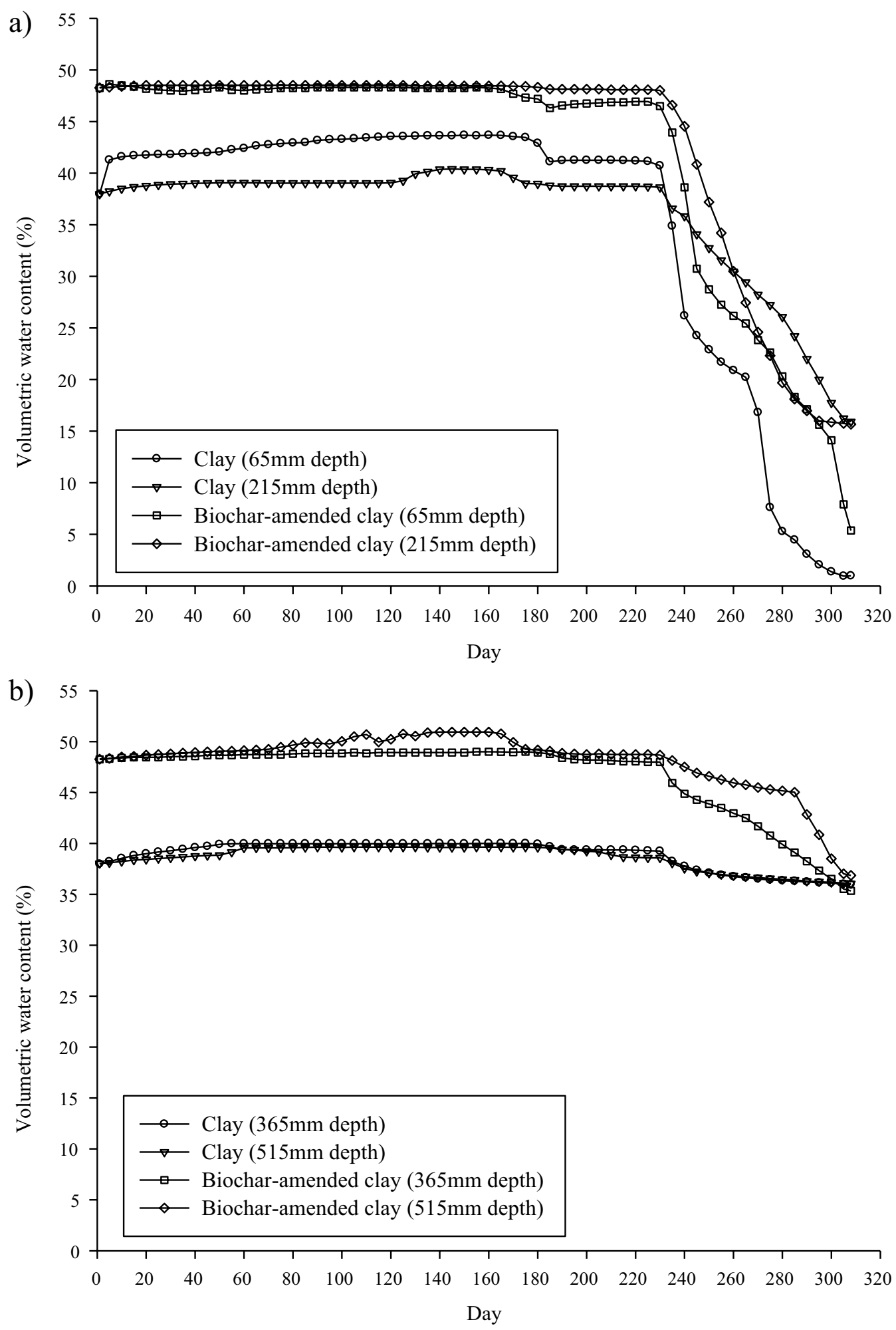

Fig. 6 Measured variations of volumetric water content with time a Rows A and B, b Rows C and D

of depths 365 and $515 \mathrm{~mm}$ before Day 230 were similar to those observed at depths 65 and $215 \mathrm{~mm}$ (Fig. 6). However, the VWC reduction of clay was slight, and the final VWCs at depths 365 and $515 \mathrm{~mm}$ were $36 \%$. For BAC, VWC dropped at a higher rate when compared with clay. The final 
VWCs at Rows depths 365 and $515 \mathrm{~mm}$ were 36 and 37\%, respectively.

Figure 7 shows the deviation of VWC along with column depth, measured by theta-probe and oven-dry methods. When compared with the actual measured (oven-dry method) VWC, theta-probes either slightly overestimated or underestimated the VWC, except for the clay column at $515 \mathrm{~mm}$. The deviation (error) of VWC measurement was only $0.57 \pm 1.46 \%$ (mean $\pm \mathrm{SD}$ ). The influence of this slight deviation on the subsequent permeability calculation can be considered negligible.

\subsection{Soil water retention curves (SWRCs)}

It was assumed that the air phase of unsaturated soil in soil columns was continuous and remained at the atmospheric pressure. Therefore, the magnitude of the negative PWP was equal to the matric suction. As a result, the SWRCs related to matric suction and the corresponding measured VWC were obtained. Figures $8 \mathrm{a}-\mathrm{d}$ show the measured wetting and drying SWRCs at depths 65 to $515 \mathrm{~mm}$, respectively. The wetting and drying SWRCs of clay and BAC followed a similar trend at all soil depths, except that soils at shallow depth were dried to a lower VWC. For instance, the clay and $\mathrm{BAC}$ in soil columns were dried to $\mathrm{VWC}<5 \%$ at the end of the drying phase (Fig. 7).
The SWRCs showed that biochar increased the soil water holding capacity of compacted clay at soil suction lower than $800 \mathrm{kPa}$. In other words, the soil water content of BAC was higher than that of clay, at the same soil suction. This may be due to the increase in organic matter content and specific surface area upon biochar application (Lei and Zhang 2013). The organic matter content of the peanut-shell biochar $(51.91 \%)$ was significantly higher $(\mathrm{p}<0.05)$ than that of kaolin clay (31.26\%) (Wong 2017). In addition, the BET SSA of biochar $\left(151.24 \mathrm{~m}^{2} \mathrm{~g}^{-1}\right)$ was approximately three times more than that of clay $\left(41.46 \mathrm{~m}^{2} \mathrm{~g}^{-1}\right)$. Biochar with high porosity and specific surface is useful to increase the soil water holding capacity of clay at suction lower than $800 \mathrm{kPa}$ (high degree of saturation) (Verheijen et al. 2010). Castellini et al. (2015) also reported that there was a positive correlation between SSA of biochar and soil water retention capacity of the amended soil. It appears that biochar application does not only increase the soil water retention capacity of non-compacted agricultural soils but also the compacted biochar-clay composite. It revealed the potential benefits of using biochar-clay composite as pollutant barriers (such as landfill cover system) to minimize shrinkage and desiccation-induced crack formation. Furthermore, phyto-capping of landfill sites is becoming popular in many countries such as Australia and China (Lamb et al. 2014; Lu et al. 2020). The incorporation of biochar in the vegetation layer can promote the growth performance of both plants

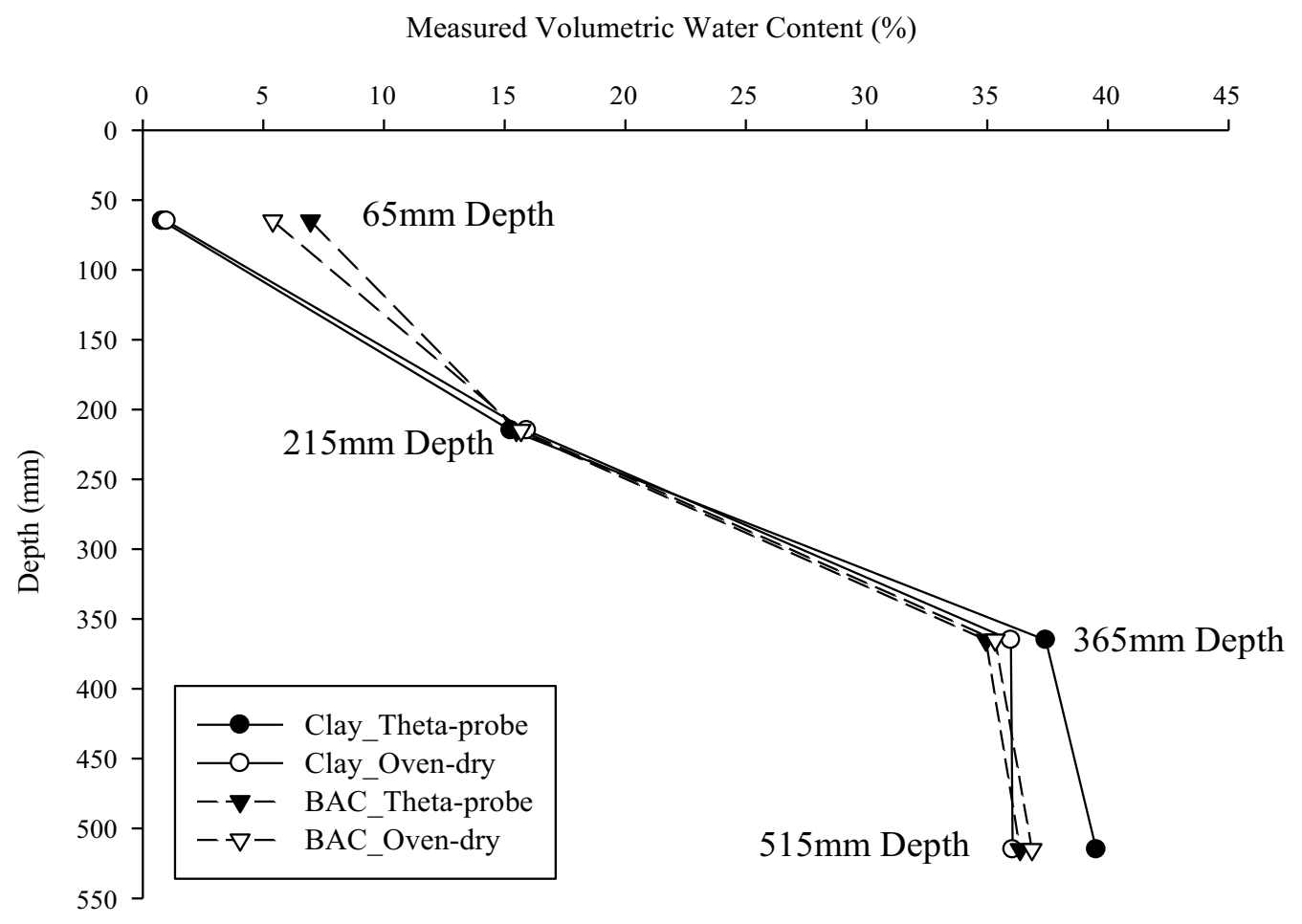

Fig. 7 Measured volumetric water content profiles by theta-probe and oven-dry method after the test 
Fig. 8 Measured drying and wetting soil water retention curves (SWRCs) of Rows a A, b $\mathrm{B}, \mathbf{c} \mathrm{C}$, and $\mathbf{d} \mathrm{D}$
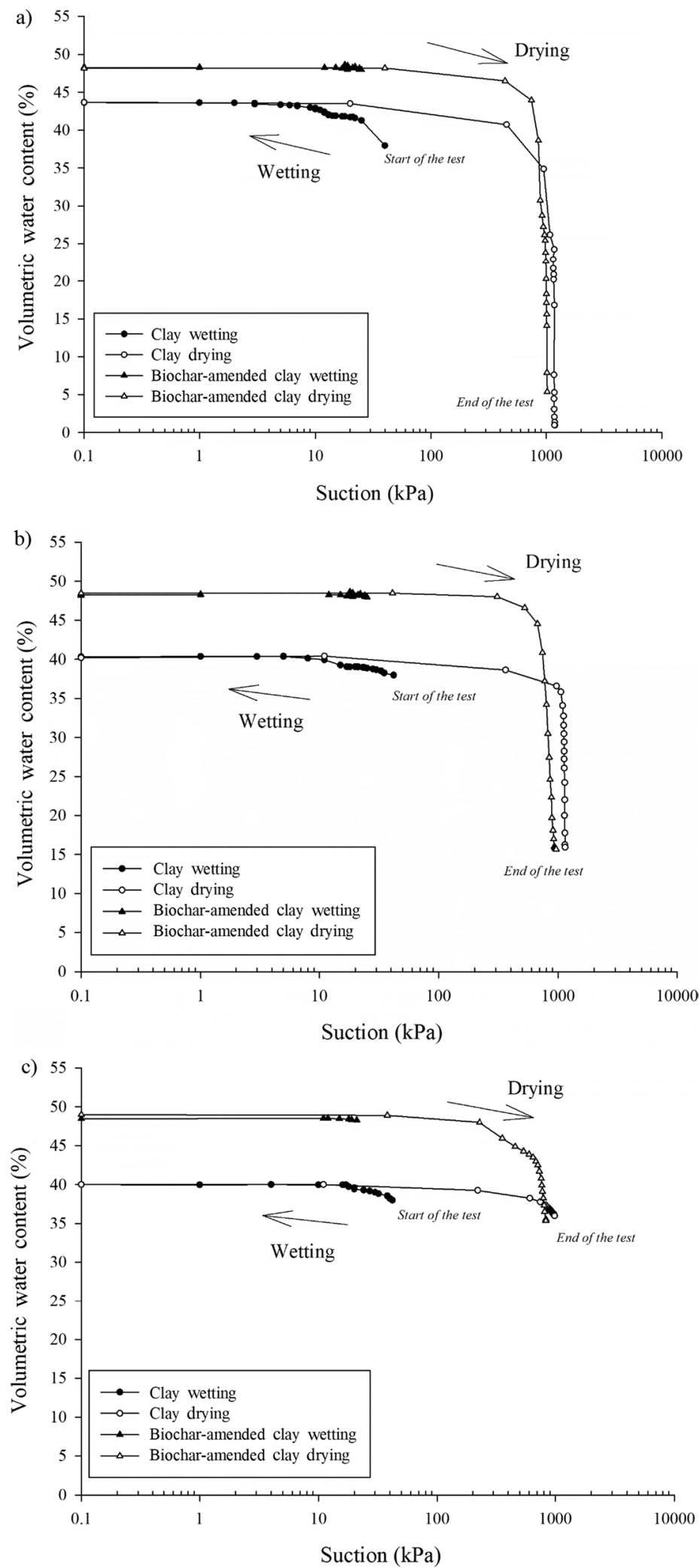
Fig. 8 (continued)

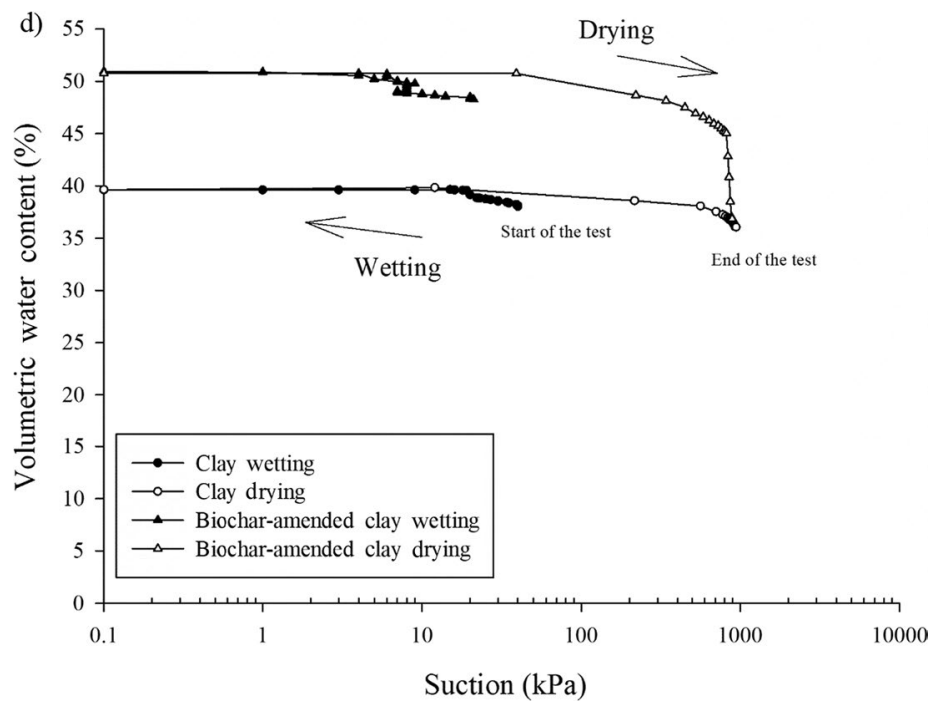

and soil microorganisms to facilitate ecological restoration (Chen et al. 2018; Wong et al. 2019).

\section{Environmental significance}

The SWRCs suggest that the biochar-clay composite possesses a higher soil water retention capacity than that of pure clay. The composite can be wetted faster and dried slower, retaining more water during drying than pure clay. A higher moisture level can prevent or minimize crack formation (Kishné et al. 2010; Tang et al. 2021). The biochar-clay composite has a higher level of threshold withstanding a period of drying and still maintains the function as a hydraulic barrier. Besides, biochar is more stable (against mineralization) when mixed with clay than when mixed with other coarse soils. Because clayey soils can interact with biochar forming stable biochar-mineral complexes (Fang et al. 2014; Yang et al. 2016; Han et al. 2020), which can serve as carbon-sink materials better than pure biochar. Furthermore, the biochar-clay composite can be used as an adsorption layer constructed beneath the industrial sites that can potentially release pollutants. The subsurface migration of pollutants can be prevented or adsorbed by the biochar-clay composite layer. Similarly, waste-based permeable reactive barriers for groundwater pollution control at e-waste recycling sites have been proposed (Beiyuan et al. 2017). In this case, geo-environmental structures requiring earthy hydraulic barriers and carbon sequestration can be integrated.

\section{Conclusions}

Biochar amendment significantly increased water retention while maintaining a relatively high matric suction of clay. The formation of desiccation-induced cracks and hydraulic conductivity of clay were thus reduced upon biochar amendment. The serviceability of the clay liner as a hydraulic barrier can be considerably improved. Adding biochar to the clay liner system can also sequester carbon and serve as an adsorbent layer of pollutants.

Supplementary Information The online version contains supplementary material available at https://doi.org/10.1007/s42773-021-00125-y.

Acknowledgements This study was funded by the Collaborative Research Fund provided by the Research Grants Council of Hong Kong (HKUST6/CRF/12R). The authors would like to thank Dr. Jason Lim Coo and Dr. Zhongkui Chen for their technical assistance.

Authors' contributions JTFW conceived the idea, designed and conducted the experiment, analyzed the data, and drafted the manuscript. KLC analyzed the data, drafted and revised the manuscript. XWC analyzed the data and revised the manuscript. MHW and CWWN supervised the project, commented on the manuscript, and acquired funding.

Funding This study was funded by the Collaborative Research Fund provided by the Research Grants Council of Hong Kong (HKUST6/ CRF/12R) and Shenzhen Science and Technology Program (KCXFZ20201221173601003).

Data availability The data that supports the findings of this study are available from the corresponding author upon reasonable request.

\section{Declarations}

Conflict of interest The authors declare no conflict of interest.

Open Access This article is licensed under a Creative Commons Attribution 4.0 International License, which permits use, sharing, adaptation, distribution and reproduction in any medium or format, as long as you give appropriate credit to the original author(s) and the source, provide a link to the Creative Commons licence, and indicate if changes were made. The images or other third party material in this article are included in the article's Creative Commons licence, unless indicated otherwise in a credit line to the material. If material is not included in 
the article's Creative Commons licence and your intended use is not permitted by statutory regulation or exceeds the permitted use, you will need to obtain permission directly from the copyright holder. To view a copy of this licence, visit http://creativecommons.org/licenses/by/4.0/.

\section{References}

Albright WH, Benson CH, Gee GW et al (2006) Field performance of a compacted clay landfill final cover at a humid site. J Geotech Geoenviron Eng 132:1393-1403. https://doi.org/10.1061/(ASCE) 1090-0241(2006)132:11(1393)

Atkinson J (2007) The Mechanics of soils and foundations, 2nd edn. CRC Press, New York

Beiyuan J, Tsang DCW, Yip ACK et al (2017) Risk mitigation by waste-based permeable reactive barriers for groundwater pollution control at e-waste recycling sites. Environ Geochem Health 39:75-88. https://doi.org/10.1007/s10653-016-9808-2

Castellini M, Giglio L, Niedda M et al (2015) Impact of biochar addition on the physical and hydraulic properties of a clay soil. Soil till Res 154:1-13. https://doi.org/10.1016/j.still.2015.06.016

Chen Y, Shinogi Y, Taira M (2010) Influence of biochar use on sugarcane growth, soil parameters, and groundwater quality. Soil Res 48:526-530. https://doi.org/10.1071/SR10011

Chen XW, Wong JTF, Ng CWW, Wong MH (2016) Feasibility of biochar application on a landfill final cover-a review on balancing ecology and shallow slope stability. Environ Sci Pollut Res 23:7111-7125. https://doi.org/10.1007/s11356-015-5520-5

Chen XW, Wong JTF, Chen ZT et al (2018) Effects of biochar on the ecological performance of a subtropical landfill. Sci Total Environ 644:963-975. https://doi.org/10.1016/j.scitotenv.2018.06.379

Cheng Q, Guo H, Feng T, Lu Y (2018) Volume changes of biocharamended landfill cover soil under a thermal cycle. Waste Manage Res. https://doi.org/10.1177/0734242X18790356

Coo JL, So ZPS, Ng CWW (2016) Effect of nanoparticles on the shrinkage properties of clay. Eng Geol 213:84-88. https://doi. org/10.1016/j.enggeo.2016.09.001

Cossu R (2018) 7.1-physical landfill barriers: principles and engineering. In: Cossu R, Stegmann R (eds) Solid waste landfilling. Elsevier, Amsterdam, pp 271-287

Dane JH, Topp CG (eds) (2002) Methods of soil analysis, part 4: physical methods. Soil Science Society of America, Madison

Delage P, Cui YJ (2008) An evaluation of the osmotic method of controlling suction. Geomech Geoeng 3:1-11. https://doi.org/10. 1080/17486020701868379

Fang Y, Singh B, Singh BP, Krull E (2014) Biochar carbon stability in four contrasting soils. Eur J Soil Sci 65:60-71. https://doi.org/ 10.1111/ejss. 12094

Favaretti M, Cossu R (2018) 7.2-mineral liners. In: Cossu R, Stegmann R (eds) Solid waste landfilling. Elsevier, Amsterdam, pp 289-312

Feng M, Fredlund DG, Shuai F (2002) A laboratory study of the hysteresis of a thermal conductivity soil suction sensor. Geotech Test J 25:303-314. https://doi.org/10.1520/GTJ11095J

Fernandes M, Denis A, Fabre R et al (2015) In situ study of the shrinkage-swelling of a clay soil over several cycles of droughtrewetting. Eng Geol 192:63-75. https://doi.org/10.1016/j.enggeo. 2015.03.017

Fredlund DG, Rahardjo H, Fredlund MD (2012) Unsaturated soil mechanics in engineering practice. John Wiley and Sons INC, New Jersey

Han L, Sun K, Yang Y et al (2020) Biochar's stability and effect on the content, composition and turnover of soil organic carbon. Geoderma 364:114184. https://doi.org/10.1016/j.geoderma.2020. 114184
Jeffery S, Meinders MBJ, Stoof CR et al (2015) Biochar application does not improve the soil hydrological function of a sandy soil. Geoderma 251-252:47-54. https://doi.org/10.1016/j.geoderma. 2015.03.022

Kishné ASZ, Morgan CLS, Ge Y, Miller WL (2010) Antecedent soil moisture affecting surface cracking of a Vertisol in field conditions. Geoderma 157:109-117. https://doi.org/10.1016/j.geode rma.2010.03.020

Krisdani H, Rahardjo H, Leong EC (2008) Effects of different drying rates on shrinkage characteristics of a residual soil and soil mixtures. Eng Geol 102:31-37. https://doi.org/10.1016/j.enggeo. 2008.07.003

Lamb DT, Venkatraman K, Bolan N et al (2014) Phytocapping: an alternative technology for the sustainable management of landfill sites. Crit Rev Environ Sci Tech 44:561-637. https://doi.org/10. 1080/10643389.2012.728823

Lehmann J, Joseph SM (2009) Biochar for Environmental Management: Science and Technology. Routledge, New York

Lei O, Zhang R (2013) Effects of biochars derived from different feedstocks and pyrolysis temperatures on soil physical and hydraulic properties. J Soils Sed 13:1561-1572. https://doi.org/10.1007/ s11368-013-0738-7

Leong EC, Zhang XH, Rahardjo H (2012) Calibration of a thermal conductivity sensor for field measurement of matric suction. Géotechnique 62:81-85. https://doi.org/10.1680/geot.9.P.008

Liu C, Wang H, Tang X et al (2016) Biochar increased water holding capacity but accelerated organic carbon leaching from a sloping farmland soil in China. Environ Sci Poll Res 23:995-1006. https:// doi.org/10.1007/s11356-015-4885-9

Lu H, Yan M, Wong MH et al (2020) Effects of biochar on soil microbial community and functional genes of a landfill cover three years after ecological restoration. Sci Total Environ 717:137133. https:// doi.org/10.1016/j.scitotenv.2020.137133

Major J, Lehmann J, Rondon M, Goodale C (2010) Fate of soil-applied black carbon: downward migration, leaching and soil respiration. Global Change Biol 16:1366-1379. https://doi.org/10.1111/j. 1365-2486.2009.02044.x

McCarthy E (1934) Mariotte's Bottle. Science 80:100. https://doi.org/ 10.1126/science.80.2065.100

Melchior S (1997) In-situ studies on the performance of landfill caps (compacted soil liners, geomembranes, geosynthetic clay liners, capillary barriers. In: In proceeding of the International Containment Technology Conference, U.S. Deptment of Energy. Germanton, Maryland, U.S.A, pp 365-373

Moragues-Saitua L, Arias-González A, Gartzia-Bengoetxea N (2017) Effects of biochar and wood ash on soil hydraulic properties: a field experiment involving contrasting temperate soils. Geoderma 305:144-152. https://doi.org/10.1016/j.geoderma.2017.05.041

Mu QY, Zhou C, Ng CWW (2020) Compression and wetting induced volumetric behavior of loess: Macro- and micro-investigations. Transp Geotech 23:100345. https://doi.org/10.1016/j.trgeo.2020. 100345

Ng CWW, Pang YW (2000) Experimental investigations of the soilwater characteristics of a volcanic soil. Can Geotech J 37:12521264. https://doi.org/10.1139/t00-056

$\mathrm{Ng}$ CWW, Leung AK (2012) Measurements of drying and wetting permeability functions using a new stress-controllable soil column. J Geotech Geoenviron Eng 138:58-68. https://doi.org/10.1061/ (ASCE)GT.1943-5606.0000560

Ng CWW, Coo JL (2014) Hydraulic conductivity of clay mixed with nanomaterials. Can Geotech J 52:808-811. https://doi.org/10. 1139/cgj-2014-0313

Ng CWW, Coo JL, Chen ZK, Chen R (2016) Water infiltration into a new three-layer landfill cover system. J Environ Eng 142:4016007. https://doi.org/10.1061/(ASCE)EE.1943-7870.0001074 
Rasa K, Heikkinen J, Hannula M et al (2018) How and why does willow biochar increase a clay soil water retention capacity? Biomass Bioenergy 119:346-353. https://doi.org/10.1016/j.biombioe.2018. 10.004

Shuai F, Fredlund DG (2000) Use of a new thermal conductivity sensor to measure soil suction. In: Advances in Unsaturated Geotechnics. American Society of Civil Engineers, Denver, Colorado, United States, pp 1-12. https://ascelibrary.org/doi/pdf/10.1061/40510\% $28287 \% 291$

Tang C-S, Zhu C, Cheng Q et al (2021) Desiccation cracking of soils: A review of investigation approaches, underlying mechanisms, and influencing factors. Earth Sci Rev 216:103586. https://doi. org/10.1016/j.earscirev.2021.103586

USEPA (Environmental Protection Agency of the United States) (1989) Technical guidance document: final covers on hazardous waste landfills and surface impoundments. U.S. Environmental Protection Agency, Washington

van Genuchten MTh (1980) A closed-form equation for predicting the hydraulic conductivity of unsaturated soils. Soil Sci Soc Am J 44:892-898. https://doi.org/10.2136/sssaj1980.036159950044000 $50002 x$

Verheijen F, Jeffery S, Bastos AC et al (2010) Biochar application to soils: a critical review of effects on soil properties, processes and functions. Europe, European Commission

Wang D, Li C, Parikh SJ, Scow KM (2019) Impact of biochar on water retention of two agricultural soils-a multi-scale analysis. Geoderma 340:185-191. https://doi.org/10.1016/j.geoderma.2019. 01.01
Wong JTF, Chen ZK, Ng CWW, Wong MH (2015) Gas permeability of biochar-amended clay: potential alternative landfill final cover material. Environ Sci Pollut Res 23:7126-7131. https://doi.org/ 10.1007/s11356-015-4871-2

Wong JTF, Chen Z, Chen X et al (2017) Soil-water retention behavior of compacted biochar-amended clay: a novel landfill final cover material. J Soils Sed 17:590-598. https://doi.org/10.1007/ s11368-016-1401-x

Wong JTF, Chen Z, Wong AYY et al (2018) Effects of biochar on hydraulic conductivity of compacted kaolin clay. Environ Pollut 234:468-472. https://doi.org/10.1016/j.envpol.2017.11.079

Wong JTF, Chen X, Deng W et al (2019) Effects of biochar on bacterial communities in a newly established landfill cover topsoil. J Environ Manage 236:667-673. https://doi.org/10.1016/j.jenvm an.2019.02.010

Wong JTF (2017) The effects of biochar on bacterial communities and geotechnical properties of landfill cover soils. PhD Thesis., The Hong Kong University of Science and Technology, Hong Kong

Yang F, Zhao L, Gao B et al (2016) The interfacial behavior between biochar and soil minerals and its effect on biochar stability. Environ Sci Technol 50:2264-2271. https://doi.org/10.1021/acs.est. $5 \mathrm{~b} 03656$

Zhou C, Chen R (2021) Modelling the water retention behaviour of anisotropic soils. J Hydrol 599:126361. https://doi.org/10.1016/j. jhydrol.2021.126361 